\title{
SOME ADVERSE EVENTS FOLLOWING IMMUNIZATION IN VETERINARY MEDICINE
}

\author{
Vesna Milićević ${ }^{1 \star}$, Ljubiša Veljović ${ }^{1}$, Jelena Maksimović-Zorić ${ }^{1}$, \\ Jadranka Žutić ${ }^{1}$, Branislav Kureljušić ${ }^{1}$, Vladimir Radosavljević ${ }^{1}$, \\ Nemanja Jezdimirović ${ }^{1}$, Sonja Radojičić ${ }^{2}$ \\ ${ }^{1}$ Institute of Veterinary Medicine of Serbia, Belgrade, Serbia \\ ${ }^{2}$ Faculty of Veterinary Medicine, University of Belgrade, Belgrade, Serbia
}

\begin{abstract}
Vaccines are a very effective tool for the prevention and eradication of infective diseases in both veterinary and human medicine. Although for safety reasons, vaccines undergo very strict controls before being placed on the market, the risk of adverse reactions is not eliminated. According to the World Health Organization (WHO), adverse event following immunization (AEFI) is any untoward medical occurrence that follows immunization and which does not necessarily have a causal relationship with the usage of the vaccine. Adverse reactions may arise as a direct consequence of immunization due to the specificity of the vaccine itself, the quality of the vaccine or the immunization errors. In addition, adverse reactions may also be the result of a coincidental relationship between the effect and immunization. However, biological mechanisms of AEFI are very complex. During the mass vaccination campaigns, when a large number of animals are vaccinated in a short period of time, adverse reactions are expected to be the most frequently reported. In Serbia, livestock is currently being vaccinated against Lumpy Skin Disease, Bluetongue, and Classical swine fever.
\end{abstract}

Keywords: vaccine, adverse event, mass vaccination

\footnotetext{
${ }^{1}$ Corresponding author: vesna.milicevic@nivs.rs
} 


\title{
PROCENA NEŽELjENIH REAKCIJA NAKON VAKCINACIJE U VETERINI
}

\author{
Vesna Milićevićc ${ }^{*}$, Ljubiša Veljović ${ }^{1}$, Jelena Maksimović-Zorić ${ }^{1}$, \\ Jadranka Žutić ${ }^{1}$, Branislav Kureljušić ${ }^{1}$, Vladimir Radosavljević ${ }^{1}$, \\ Nemanja Jezdimirović ${ }^{1}$, Sonja Radojičić ${ }^{2}$ \\ ${ }^{1}$ Naučni institut za veterinarstvo Srbije, Beograd, Srbija \\ ${ }^{2}$ Fakultet veterinarske medicine, Univerzitet u Beogradu, Beograd, Srbija
}

\section{Kratak sadržaj}

Vakcine su veoma efikasan alat za prevenciju i iskorenjivanje infektivnih bolesti u veterinarskoj i humanoj medicini. Iako iz sigurnosnih razloga vakcine prolaze kroz vrlo stroge kontrole pre stavljanja u promet, rizik od neželjenih reakcija nije eliminisan. Prema Svetskoj zdravstvenoj organizaciji (SZO), neželjeni događaj nakon imunizacije je svaka neugodna medicinska pojava koja prati imunizaciju i koja ne mora nužno imati uzročnu vezu sa upotrebom vakcine. Neželjene reakcije mogu nastati kao direktna posledica imunizacije usled specifičnosti same vakcine, kvaliteta vakcine ili grešaka prilikom imunizacije. Pored toga, neželjene reakcije mogu biti i posledica slučajnog odnosa između nastalog efekta i imunizacije. Međutim, biološki mehanizmi nastanka ovih reakcija su veoma složeni. Tokom kampanja masovnih vakcinacija, kada se veliki broj životinja vakciniše u kratkom vremenskom periodu, očekuje se da se neželjene reakcije najčešće prijavljuju. U Srbiji se stoka trenutno vakciniše protiv bolesti kvrgave kože, bolesti plavog jezika i klasične svinjske kuge. Pošto nijedna od ove tri vakcine nije DIVA, praćenje neželjenih događaja koji se mogu pojaviti je od izuzetnog značaja.

Ključne reči: vakcina, neželjena reakcija, masovna vakcinacija

\section{INTRODUCTION}

Vaccines are a very effective tool for the prevention and eradication of infective diseases in both veterinary and human medicine. Vaccines are, also, used to improve the welfare of companion animals as well as to treat the noninfectious diseases such as allergies or cancer, even to increase production and fertility of livestock (Meeusen et al., 2007). Immuno-contraception of pests is also based on vaccine use (Hardy et al, 2006). Effects of vaccinations are 
remarkable and measurable, particularly with regard to the cost. Thanks to the massive vaccination, among the other applied measures, the Rinderpest was declared as eradicated worldwide by the OIE and FAO in May and June 2011 (Roeder et al, 2013). Classical swine fever (CSF) has been successfully eradicated from some countries including EU member states, Canada, United States, Australia and New Zealand, where the use of the vaccine was of the highest contribution (Greiser-Wilke and Moening, 2004). World Health Organization (WHO, 2018) announces the elimination of human rabies transmitted by dogs by 2030 through the affordable human vaccines and antibodies and mass dog vaccination supported by increased communication, awareness and education.

Today, in veterinary medicine, the most used vaccines are modified live vaccines (MLV), killed (KV), and toxoid type vaccines, each characterized by advantages and disadvantages. While live vaccines typically stimulate more rapid, stronger, and longer-lasting immunity than killed vaccines, using the killed vaccines there is no risk of the vaccine organism spreading between animals as well as the risk of causing abortion is minimal (Jorge and Dellagostin, 2017). MLVs are mainly available for diseases caused by viruses, such as bovine herpesvirus 1, bovine viral diarrhea virus (BVDV), bovine respiratory syncytial virus (BRSV), and parainfluenza-3 virus (Pl3). KVs usually contain adjuvants, or added substances, that further stimulate the immune system to respond to the vaccine challenge. Even more, the majority of KVs are safe to use in any animal, including pregnant ones (Jorge and Dellagostin, 2017).

Apart from the vaccine formulation, the administration route and the method of vaccination influence on the efficacy and safety of a vaccine.

Usually, in the veterinary medicine, the vaccines are administered parenterally via intramuscular, subcutaneous and intradermal injection. The mucosal immunization includes intraocular, intranasal and/or oral administration. Mucosal application of attenuated vaccines via drinking water or spray, being very successful, is now routinely applied in poultry (Makoschey, 2015). The oral administration of rabies vaccine in vaccination of wild carnivores has had a great contribution to the rabies control and eradication (Lupulović et al, 2015). Oral vaccine for classical swine fever, after having been used since years for the CSF control and eradication of CSF in wild boar, is now recommended for domestic pigs vaccination, particularly for those kept extensively, in backyards (Milićević et al., 2013; Dietze et al., 2013). 


\section{ADVERSE EVENT FOLLOWING IMMUNIZATION (AEFI)}

Although for safety reasons, vaccines undergo very strict controls before being placed on the market, the risk of adverse reactions is not eliminated. According to the World Health Organization (WHO, 2018), adverse event following immunization is any untoward medical occurrence that follows immunization and which does not necessarily have a causal relationship with the usage of the vaccine.

AEFIs are grouped into five categories: vaccine product-related reaction, vaccine quality defect-related reaction, immunization error-related reaction, immunization anxiety-related reaction and coincidental event (WHO, 2018).

Biological mechanisms of AEFI are very complex. Very often, the latency between antigen exposure and peak adaptive immune response, due to the adjuvants that help to increase the response rates to vaccines, results in prolonged exposure of the immune system cells to antigen and consequently the release of inflammatory mediators. Further on, the tissue damage or clinical disease occurrence following the immunization could be related to some of the immune-mediated mechanisms such as effector functions of $\mathrm{T}$ cells, effector functions of antibodies and autoantibodies, complement activation, hypersensitivity reactions etc. (Stratton, 2012).

Attenuated live viral vaccines can cause the same effects through the same mechanisms like it happens during the natural infection. Such events occur usually when the immune system is impaired or the animal immunocompromised. Some of the adverse events, like complex regional pain syndrome, syncope etc., are not directly related to the contents of the vaccine but rather to the adverse event of direct trauma from the needle (Stratton, 2012).

AEFIs can be manifested as either local or systemic reactions. Minor local reactions include pain, redness and swelling at the injection site within 48 hours of vaccination. Such reactions that extend past the nearest joint and/or persisting for 10 days or more should be reported (WHO, 2018). Arthus Reaction is a major local reaction manifested with 48 hours after the immunization as a large, localized reaction characterized by pain, swelling, induration, and edema. This reaction usually occurs when there is a large number of circulating antibodies prior to injection of the antigen. Most Arthus reactions resolve within one week. Abscess at the injection site is a swollen lump, fluid-filled, becoming very painful which usually appears within 7 days after immunization due to the bacterial contamination. The sterile abscess can persist for more than 1 month. Nodules are solid, elevated areas of tissue at the injection site with discrete or well-demarcated borders. Normally, nodules are not accom- 
panied either with abscess formation, erythema or warmth. They are mainly caused by aluminum-based adjuvants and subcutaneous route of administration. Sterile nodules can take up to 1 year or more to resolve.

Cellulitis at the injection site is an acute inflammation of the subcutaneous tissue, fat, fascia or muscle, usually seen within 7 days after vaccine administration due to the bacterial contamination (WHO, 2018).

Fever is the most often seen systemic reaction. It appears within 72 hours when killed vaccines are used, while this time is prolonged with the live vaccines. A fever that begins within 24 hours after vaccination with the inactivated vaccine or persists for more than 24 hours after vaccination should not be assumed to be due to the vaccine (WHO, 2018).

The enlargement of one or more lymph nodes is usually associated with some adjuvants that produce transient chemokine and cytokine stimulation, enhanced the local activity of antigen presenting cells, and uptake by regional lymph nodes. However, the live vaccines, due to a low-grade infection, can cause the adenopathy (WHO, 2018).

Allergic reactions are an acquired hypersensitivity to a component of the vaccine. They are usually manifested as a mild form of the dermatological/mucosal and/or the respiratory systems disorders. Allergic reactions occur within 48 hours of immunization. However, anaphylaxis, a type of allergic reaction, is the potentially life-threatening adverse reaction to the immunization. It is manifested by sudden onset, rapid progression of signs and symptoms and involvement of multiple organ systems (WHO, 2018).

Many other reactions such as neurological disorders, thrombocytopenia, arthritis etc., can also be related to the immunization.

In the veterinary medicine, the most common side effects include transient swelling at the site of injection and a reaction that may change coat color in the area, transient pyrexia, respiratory distress, salivation, vomiting, diarrhea, urticaria, reduced fertility, fetal deformities and abortion (Morton, 2007). However, immune-mediated hemolytic anemia (IMHA), thrombocytopenia (IMTP), polyneuritis and polyarthritis are autoimmune disorders (primarily in the dog) that can, also, be linked to vaccination (Day, 2006). Hypersensitivity type III where the cutaneous vasculopathy occurs has been reported following rabies virus vaccination. Similarly, the formation and the deposition of immune complexes are the cause of adenoviral-related 'blue eye' in dogs. As a different category of adverse events, Day (2006) states the lack of efficacy although it is more often due to the inappropriate administration, or administration to immunosuppressed or immunodeficient individuals than to batches of subnormal efficacy. The effects that can occur due to the residual virulence 
of attenuated vaccine strains, or batch contamination during manufacture are also considered as adverse events (Day, 2006).

\section{MASS VACCINATION CAMPAIGNS IN SERBIA}

In Serbia, livestock is currently being vaccinated against Lumpy Skin Disease, Bluetongue, and Classical swine fever. During the mass vaccination campaigns, when a large number of animals are vaccinated in a short period of time, adverse reactions are expected to be the most frequently reported.

\section{BLUETONGUE DISEASE VACCINATION}

Vaccination against bluetongue disease has been implemented in European countries after the incursion of the disease in 1998 (Niedbalski, 2011). At that time, modified live vaccines were commercially available and used for mass vaccination of cattle and sheep. Besides the high level of immunogenicity and protection, it has been shown that modified live vaccine caused significant side reactions. Adverse events such as fever, facial oedema, lameness, reduced milk production, and teratogenicity were reported mostly in sheep. Abortions were recorded in less than $0.5 \%$ of vaccinated animals (Savini et al., 2008b). Those reactions are commonly attributed to under-attenuation of the modified strains and their capacity of passing the placental barrier, and the spread of vaccine strain in the environment with the potential for reversion to virulence and re-assortment with field isolates (Savini et al., 2008a). It has been shown that viremia of attenuated vaccine strain lasts up to 35 days, even reaching a titer which enables infection of Culicoides (Savini et al., 2008b). Circulation of vaccine strains has been confirmed in the Netherlands (BTV6), Germany (BTV6), Belgium (BTV11), and BTV14 in Lithuania, Latvia, Poland, and Estonia ${ }^{1}$. De Leeuw et al. (2015) also reported the possible detection of RNA in circulation after vaccination against BTV8. The severity of adverse events depends also on BTV genotype. BTV16 in attenuated vaccines produced the most severe reactions (Savini et al., 2008b). Inactivated vaccines have, also, been commercialized, initially against BTV2 and BTV4, but afterward for all circulating strains in EU (Wilson and Mellor, 2009). Thus, the risk of adverse events following immunization with MLV was minimized. However, for the full protection and prevention of both clinical symptoms and viremia, two doses of inactivated vaccines are needed (Savini et al., 2008a). Many studies carried out to evaluate the safety of inactivated vaccines demonstrated well tolerance and absence

${ }^{1}$ https://ec.europa.eu/food/animals/animal-diseases/control-measures/bluetongue_en 
of the systemic reaction (fever, weight loss, reproductive dysfunction) related to vaccination. However, some animals developed transient local reactions of variable severity with a different frequency (Savini et al., 2008a) which usually disappeared within 3 days. In a single case, a moderate local reaction persisted for 2 weeks (Hamers et al., 2006). Anaphylaxis was only reported in animals which previously received MLV. Neither side effects nor local reactions in safety studies for cattle have been reported even when five doses of the BTV-4 inactivated vaccine was administered to the same animal (Savini et al., 2008a). Inactivated BTV4 vaccine has been used in Serbia since 2015. Expected adverse events are the slight increase in body temperature and appearance of the nodule at the injection site. According to the manufacturer's instruction, it can be expected that up to $53 \%$ of vaccinated animals display the nodules which should disappear within 35 days in sheep or even longer in cattle.

\section{LUMPY SKIN DISEASE VACCINATION}

Lumpy skin disease was confined to African continent until 1989 when occurred in Israel, for the first time outside Africa. When the disease was introduced in Turkey and Iraq in 2013, its potential for further spread was evident. By the year 2016 the virus was detected in seven European countries - Greece, Bulgaria, the Former Yugoslav Republic of Macedonia, Serbia, Albania, Montenegro, and Kosovo. For the disease control and eradication, vaccination has been immediately implemented. Live attenuated vaccines are the most commonly used. There are currently two types of them, derived either from the South-African LSDV Neethling strain or an attenuated LSDV field strain. However, even heterologous vaccines can be used but provide incomplete protection. Abutarbush et al. (2016) reported that duration between vaccine administration and appearance of adverse clinical signs ranged from 1 to 20 days. Clinical manifestations which included fever, decreased feed intake, decreased milk production and variable sized cutaneous nodules lasted from 3 to 20 days. However, no mortalities were reported due to vaccine adverse reactions. Croatia reported adverse events on $0.24 \%$ of the vaccinated farms, involving $0.09 \%$ of the total animals affected and $0.02 \%$ deaths (EFSA, 2017). Commonly, the symptoms appeared within 2 weeks after vaccination and included fever (22\%), a decrease in milk production (27\%), edema at injection site (21\%), lumps (12\%), erythema (7\%), abortions (7\%) and ataxia (5\%) of affected animals. Katsoulos et al. (2016) described that in Greece 12\% of animals had the pronounced swelling at injection-site while $10 \%$ of animals developed small-sized skin nodules. The milk production was reduced up to $16 \%$ during 
the first 12 days post-vaccination. Vaccine virus was detectable in blood between 6 and 15 days post vaccination as well as in aspirates obtained from the injection-site lesions and in nodule biopsies suggesting the need for DIVA vaccine. Despite the evident adverse effects, it has been shown that vaccine based on attenuated Neethling strain was 4.3 times more effective in preventing laboratory-diagnosed LSD than the sheep pox vaccine, and 11.2 times more effective in preventing severe LSD cases (Ben-Gera et al., 2015). Though massive vaccination in many countries has been implemented, there is no evidence of the vaccine strain regaining virulence or spreading of the disease via cattle products (Tuppurainen and Galon, 2016).

\section{CLASSICAL SWINE FEVER VACCINATION}

To control and eradicate classical swine fever, the safe and highly efficacious live attenuated vaccine based on China strain (C strain) has been used since years in Serbia. Apart from the traditionally used intramuscular vaccine, the formulation for oral administration has also been confirmed as efficient and safe (Milićević et al., 2013). In order to enable differentiation between vaccine and field strain, many other vaccines were developed. However, it has been shown that the best candidate is the recombinant CP7_E2alf vaccine (Blome et al., 2017).

Blome et al. (2006) showed that vaccine based on attenuated C strain could cause no damage in vaccinated animals. The $\mathrm{C}$ strain was not interfered with gestation, though it passages through the placental barrier. Therefore the vaccine was safe for use in pregnant animals, even in immunosuppressed ones. The same authors reported that E2 subunit vaccines were also highly safe, apart from a possible local tissue reaction at the injection site (Blome et al., 2017).

As other, MLV for CSF is detectable for some time after vaccination. However, though the genome of the CP7_E2alf vaccine is detectable by RT-PCR in tonsils and lymph nodes for up to 63 days, the shedding of vaccine virus has not been detected. Similarly, orally vaccinated pigs did not transmit vaccine virus to susceptible contact animals. However, the genome of $\mathrm{C}$ strain virus after orally administered vaccine could be detected in the tonsil 21 days post-vaccination (dpv) (Kaden et al., 2010). Even more, the absence of leucopenia after vaccination and no increase of virulence were reported up to now (Koenig et al., 2007).

Adverse events following vaccination in veterinary medicine, particularly if mandatory mass vaccination is applied, are accomplished to the compensation. However, despite the reporting system is available, so far there are no official reports on adverse events in Serbia. 


\section{REFERENCES}

1. Abutarbush S.M., Hananeh W.M., Ramadan W., Al Sheyab O.M., Alnajjar A.R., Al Zoubi I.G., Knowles N.J., Bachanek-Bankowska K., Tuppurainen E.S.: Adverse Reactions to Field Vaccination Against Lumpy Skin Disease in Jordan. Transboundary and Emerging Diseases, 63, 2, 213-9, 2016.

2. Ben-Gera J., Klement E., Khinich E., Stram Y., Shpigel N.Y.: Comparison of the efficacy of Neethling lumpy skin disease virus and 10x RM65 sheeppox live attenuated vaccines for the prevention of lumpy skin disease - the results of a randomized controlled field study. Vaccine, 33, 4837-42, 2015.

3. Blome S., Meindl-Bohmer A., Loeffen W., Thuer B., Moennig V.: Assessment of classical swine fever diagnostics and vaccine performance. Scientific and Technical Review of the Office International des Epizooties, 25, 3, 1025-38, 2006.

4. Blome S., Wernike K., Reimann I., Konig P., Mos C., Beer M.: A decade of research into classical swine fever marker vaccine CP7_E2alf (Suvaxyn ${ }^{\circ}$ CSFMarker): a review of vaccine properties. Veterinary Research, 48, 51, 2017.

5. Day M.J.: Vaccine side effects: Fact and fiction. Veterinary Microbiology, 117, 1, 51-58, 2006.

6. De Leeuw I., Garigliany M., Bertels G., Willems T., Desmecht D., De Clercq K.: Bluetongue virus RNA detection by real-time RT-PCR in postvaccination samples from cattle. Transboundary and Emerging Diseases, 62, 2, 157-62, 2015.

7. Dietze K., Milicevic V., Depner K.: Prospects of improved classical swine fever control in backyard pigs through oral vaccination. Berl Münch Tierärztl Wschr, Berliner und Munchener Tierarztliche Wochenschrift 126, Heft 11/12, Seien 476-480, 2013.

8. European Food Safety Authority (EFSA): Lumpy skin disease: I. Data collection and analysis. EFSA Journal. 15, 4, 4773-4827, 2017.

9. Greiser-Wilke I., Moennig V.: Vaccination against classical swine fever virus: Limitations and new strategies. Animal Health Research Reviews, 5, 223-226, 2004.

10. Hamers C., Werle-Lapostolle B., Rehbein S., Blanchet M., Mure-Ravaud K., Schumacher C., Hudelet P.: Six month efficacy of an inactivated BTV-2 industrial vaccine against a virulent BTV-2 challenge in sheep. In: Proceedings of the ninth international symposium on double-stranded RNA viruses, Cape Town, South Africa, 21-26 October 2006.

11. Hardy C.M., Hinds L.A., Kerr P.J., Lloyd M.L., Redwood A.J., Shellam 
G.R., Strive T.: Biological control of vertebrate pests using virally vectored immunocontraception. Journal of Reproductive Immunology, 71, 2, 102-11, 2006.

12. Jorge S., Dellagostin O.A.: The development of veterinary vaccines: a review of traditional methods and modern biotechnology approaches. Biotechnology Research and Innovation, 1, 6-13, 2017.

13. Kaden V., Lange E., Kuster H., Muller T., Lange B.: An update on safety studies on the attenuated "RIEMSER Schweinepestoralvakzine" for vaccination of wild boar against classical swine fever. Veterinary Microbiology, 143, 2-4, 133-8, 2010.

14. Katsoulos P.D., Dovas C.I., Chaintoutis S.C., Polizopouloub Z., Papadopoulos O., Karatzias H., Boscos C.: Virological evaluation and clinical impact of field vaccination against lumpy skin disease in cattle. International Journal of Infectious Diseases, 53S, 145-6, 2016.

15. Koenig P., Hoffmann B., Depner K.R., Reimann I., Teifke J.P., Beer M.: Detection of classical swine fever vaccine virus in blood and tissue samples of pigs vaccinated either with a conventional C-strain vaccine or a modified live marker vaccine. Veterinary Microbiology, 120, 343-351, 2007.

16. Lupulović D., Maksimovic Zoric J., Vaskovic N., Bugarski D., Plavsic B., Ivanovic N., Petrovic T., Pusic I., Marcic D., Grgic Z., Lazic S.: First Report on the Efficiency of Oral Vaccination of Foxes against Rabies in Serbia. Zoonoses Public Health, 62, 8, 625-36, 2015.

17. Makoschey B.: Modes of vaccine administration at a glance. Berl Munch Tierarztl Wochenschr, 128, 11-12, 451-5, 2015.

18. Meeusen E.N., Walker J., Peters A., Pastoret P.P., Jungersen G.: Current Status of Veterinary Vaccines. Clinical Microbiology Reviews, 20, 3, 489-510, 2007.

19. Milićević V., Dietze K., Plavsic B., Tikvicki M., Juliio P., Depner K.: Oral vaccination of backyard pigs against classical swine fever. Veterinary Microbiology, 163, 1-2, 167-71, 2013.

20. Morton D.B.: Vaccines and animal welfare. Scientific and Technical Review of the Office International des Epizooties, 26, 1, 157-163, 2007.

21. Niedbalski W.: Bluetongue vaccines in Europe. Polish Journal of Veterinary Sciences, 14, 2, 299-304, 2011.

22. Roeder P., Mariner J., Kock R.: Rinderpest: the veterinary perspective on eradication. Philosophical transactions of the Royal Society of London. Series B, Biological sciences, 368, 1623, 2012139, 2013.

23. Savini G., Hamers C., Conte A., Migliaccio P., Bonfini B, et al.: Assessment of efficacy of a bivalent BTV-2 and BTV-4 inactivated vaccine by vaccination 
and challenge in cattle. Veterinary Microbiology, 133, 1-2, 2008 a.

24. Savini G., MacLachlan N.J., Sanchez-Vizcaino J.M., Zientara S.: Vaccines against bluetongue in Europe. Comparative Immunology, Microbiology \& Infectious Diseases, 31, 101-120, 2008b.

25. Stratton K.R.: Adverse Effects of Vaccines: Evidence and Causality. Washington, D.C: National Academies Press, 2012. Print

26. Tuppurainen E., Galon N.: Lumpy Skin Disease: Current situation in Europe and neighbouring regions and necessary control measures to halt the spread in South-east Europe. Europe - OIE Regional Commission. 2016.

27. WHO: Causality assessment of an adverse event following immunization (AEFI): user manual for the revised WHO classification (Second edition). Geneva: World Health Organization; 2018. License: CC BY-NC-SA 3.0 IGO.

28. Wilson A.J, Mellor P.S.: Bluetongue in Europe: past, present and future. Philosophical transactions of the Royal Society of London. Series B, Biological sciences, 364, 1530, 2669-81, 2009.

Primljeno: 10.04.2018.

Odobreno: 19.06.2018. 
